\title{
PENINGKATAN MUTU PRODUK KELOMPOK USAHA PENGRAJIN ECENG GONDOK DI DESA SEMULA JADI KEC. DATUK BANDAR TIMUR KOTA TANJUNG BALAI DENGAN PERBAIKAN TEKNOLOGI PRODUKSI PADA PROSES FINISHING PRODUK
}

\author{
Buchari, Afan Gunawan Ahmad, Nismah Panjaitan \\ Universitas Sumatera Utara
}

\begin{abstract}
Abstrak
Tujuan dari program pemberdayaan masyarakat ini adalah untuk meningkatkan mutu produk Kelompok Usaha Pengrajin Eceng Gondok di Desa Semula Jadi Kec. Datuk Bandar Timur Kota Tanjung Balai melalui inovasi produk dan perbaikan teknologi finishing produk. Metode pelaksanaan kegiatan pengabdian tersebut adalah dengan melaksanakan pelatihan inovasi produk dan teknologi finishing produk (pewarnaan) agar dapat meningkatkan inovasi produk dan pengembangan mutu produk pengrajin eceng gondok. Produk inovasi berbahan eceng gondok yang di buat adalah kursi, meja dan sandal. Para pengrajin melakukan praktek langsung selama mengikuti pelatihan. Selain inovasi produk, para pengrajin juga mendapat pelatihan teknik pewarnaan dengan menggunakan gun spray + kompresor dan teknik celup. Produk hasil inovasi para pengrajin diwarnai dalam sesi pelatihan yang diberikan sehingga para pengrajin mudah mengerti teknik pewarnaan yang diajarkan. Dengan perbaikan tersebut diharapkan produk kelompok pengrajin eceng gondok memiliki mutu yang baik sehingga produk-produk inovasi yang dihasilkan memiliki daya saing.
\end{abstract}

Kata Kunci : pengrajin eceng gondok, inovasi produk, teknik pewarnaan

\section{Pendahuluan}

Kerajinan enceng gondok merupakan salah satu hasil seni budaya Indonesia yang memiliki nilai jual yang tinggi. Kerajinan enceng gondok merupakan warisan dari nenek moyang dengan bahan baku dari daerah setempat.

Di Kota Madya Tanjung Balai terdapat sektor industri kreatif yang memiliki potensi besar untuk dikembangkan, yaitu industri kerajinan enceng gondok. Industri yang memanfaatkan kreativitas, ketrampilan, dan bakat ini belum banyak digeluti oleh orang lain. Padahal, produk kerajinan eceng gondok tersebut banyak sekali variasi produknya, antara lain berupa tas, tempat tisue, keranjang, souvenir berbentuk kerang, nampan, celengan, piring, hiasan, tudung saji, meja, rak buku. Pengrajin dibagi ke dalam kelompok. Terdapat 7 (tujuh) kelompok pengrajin di Kecamatan Datuk Bandar Timur, yang terdiri atas 10 orang pengrajin dalam satu kelompok.

Kelompopk Melati merupakan salah satu Kelompok usaha Pengrajin Eceng
Gondok di Kec. Datuk Bandar Timur Kota Tanjung Balai yang berada di Jalan A. Sani Str Gg. Semangka LK II, Kelurahan Semula Jadi. Kelompok usaha Melati sendiri telah mendapat izin perdagangan dari tahun 2012. Kelompok ini didirikan oleh Bapak Supriyanto yang merupakan ketua UKM di Pulau Simardan. Bapak Supriyanto telah memiliki banyak piagam penghargaan sebagai kelompok UKM terbaik dari berbagai lomba dan pameran serta mendapatkan sertifikat sebagai trainerl pelatih bagi orang-orang yang ingin mengasah kemampuan sebagai pengrajin. Siapa saja dapat ikut bergabung ke dalam Kelompok pengrajin ini dengan modal niat dan kreatifitas yang tinggi.

Berdasarkan analisis situasi diatas, kelompok usaha Pengrajin Eceng Gondok Kelompok Melati yang menjadi mitra masih mengalami berbagai permasalahan tersebut yaitu:

1. Permasalahan terkait produksi 
Buchari. et al. Peningkatan Mutu Produk Kelompok Usaha Pengrajin Eceng Gondok...

a. Peralatan yang digunakan dalam proses finishing produk masih menggunakan peralatan tradisional

b. Teknik pewarnaan yang kurang baik sehingga produk yang dihasilkan kurang menarik

2. Permasalahan terkait dengan pemasaran

a. Jaringan pemasaran yang dimiki sangat sempit.

b. Pengrajin belum memahami strategi pemasaran produk

Melihat kompleksitas permasalahan yang masih dimiliki Kelompok Usaha mitra dan keterbatasan dari tim pelaksana pengabdian masyarakat, maka diperlukan prioritas terhadap permasalahan yang akan diatasi melalui kegiatan pengabdian ini. Berdasarkan analisis kebutuhan yang telah dilakukan, maka permasalahan yang diprioritaskan untuk diatasi melalui kegiatan pengabdian ini adalah 1. Penerapan teknologi tepat guna dalam proses finishing, 2. Peningkatan kapasitas teknik pewarnaan produk.

\section{Metode Pelaksanaan}

Metode yang akan diterapkan dalam kegiatan pengabdian ini terdiri dari beberapa tahapan kegiatan yang disusun dalam satu kerangka kerja, dimana kerangka kerja akan dijelaskan sebagai berikut.

\section{a. Sosialisasi dan Identifikasi kebutuhan teknologi}

Tahap awal untuk pendekatan teknologi pewarnaan adalah adanya sosialisasi teknologi terhadap para pengrajin. Nilai-nilai yang didapat jika dapat memperbaiki teknik pewarnaan kerajinan dengan baik. Sosialisasi ini diharapkan dapat meningkatkan minat para pengrajin agar mau berusaha lebih untuk meningkatkan mutu produk kerajinan yang dihasilkan kelompok Melati

\section{b. Pengadaan peralatan Finishing, Alat Kompresor lengkap dengan Alat Pewarnaan.}

Penerapan Alat kompresor lengkap dengan alat filter dan air brush cat semprot untuk pewarnaan pada saat finishing produk. Tingkat semprotan yang rendah membuat pengecatan merata dan bagus. Peralatan Kompresor lengkat dengan alat pewarnaan akan diberikan pada kelompok usaha pengrajin Eceng Gondok kelompok Melati. Akan dilakukan demo penggunaan alat kepada pengrajin.

\section{c. Pelatihan Teknik Pewarnaan}

Pelatihan ditujukan kepada pengrajin eceng gondok kelompok Melati. Materi pelatihan berupa teknik-teknik pewarnaan yang sesuai kebutuhan aktifitas pengrajin eceng gondok. Adapun langkah-langkah dalam melaksanakan kegiatan pelatihan tersebut diantaranya :

1. Perumusan materi pelatihan yang mudah dipahami oleh para pengrajin

2. Membuat modul pelatihan mengenai teknik-teknik pewarnaan dengan menggunakan alat kompresor

3. Melatih para pengrajin untuk pewarnaan produk kerajinan yang dihasilkan.

\section{Evaluasi hasil pelaksanaan program.}

Evaluasi dilakukan terhadap peningkatan kualitas kerajinan eceng gondok dan ketrampilan para pengrajin mewarnai produk kerajinan menggunakan alat kompresor. Bahan evaluasi diperoleh dengan melakukan pengamatan dan pengukuran lapangan, pengumpulan pendapat, tanggapan dan saran mitra.

\section{Hasil dan Pembahasan}

\section{A. Persiapan}

Persiapan kegiatan berupa survei dan kunjungan pendahuluan ke kelompok usaha pengrajin eceng gondok Kelurahan Semula jadi Kecamatan Datuk bandar Timur Kota Tanjung Balai. Kegiatan Persiapan meliputi :

a. Melakukan komunikasi awal tentang rencana kegiatan pengabdian antara Tim pelaksana dengan kelompok usaha pengrajin eceng gondok Kelurahan Semula jadi Kecamatan Datuk bandar Timur Kota Tanjung Balai.

b. Tim Pengabdi melakukan diskusi dengan kelompok usaha pengrajin eceng gondok 
Buchari. et al. Peningkatan Mutu Produk Kelompok Usaha Pengrajin Eceng Gondok...

tentang kebutuhan kegiatan pengabdian yang akan dilakukan.

c. Tim pengabdi bersama dengan kelompok usaha pengrajin eceng gondok menentukan jadwal pelaksanaan kegiatan dan disepakati secara bersama.

d. Menentukan dan mendiskusikan jenis partisipasi mitra untuk mendukung setiap kegiatan yang diusulkan oleh Tim Pelaksana kegiatan pengabdian.

\section{B. Pelaksanaan Kegiatan pengabdian}

Adapun pelaksanaan kegiatan pengabdian masyarakat meliputi beberapa kegiatan diantaranya :

1. Pengembangan produk kerajinan eceng gondok dengan melakukan inovasi produk kerajinan. Produk inovasi yang dikembangkan pada kelompok usaha pengrajin eceng gondok adalah kursi, meja, dan sandal berbahan eceng gondok. Desain produk kursi, meja dan sandal diberi sentuhan kreatifitas dalam bentuk, motif dan warna produk sehingga produk yang dihasilkan lebih berkualitas dan berdaya saing.

2. Peningkatan kemampuan pewarnaan produk bagi kelompok usaha pengrajin eceng gondok. Para pengrajin diberikan pelatihan teknik pewarnaan. Teknik pewarnaan yang diberikan ada 2 cara, Teknik pewarnaan dengan Gun Spray menggunakan compressor dan teknik celup.

Kegiatan pengabdian yang dilakukan Tim Pelaksana adalah pelatihan dan praktek pada kelompok pengrajin eceng gondok Kelurahan Semula Jadi kec. Datuk bandar Timur Kota Tanjung Balai.

Tahapan kegiatan pengabdian tersebut selanjutnya disajikan di Tabel 1.

\begin{tabular}{lll}
\hline No & \multicolumn{1}{c}{ Kegiatan } & \multicolumn{1}{c}{ Pelaksana } \\
\hline A. & Persiapan & \multicolumn{1}{c}{} \\
\hline 1. & $\begin{array}{l}\text { Persiapan dan kunjungan pendahuluan ke lokasi kelompok } \\
\text { pengrajin eceng gondok, Kelurahan Semua jadi, Kec. } \\
\text { Datuk Bandar Timur Kota Tanjung Balai, Jumat, 30 } \\
\text { September 2016 }\end{array}$ & $\begin{array}{l}\text { Pelaksana kegiatan dan Kelompok } \\
\text { pengrajin eceng gondok. }\end{array}$ \\
\hline 2. & $\begin{array}{l}\text { Komunikasi awal rencana kegiatan dengan kelompok } \\
\text { pengrajin eceng gondok }\end{array}$ & $\begin{array}{l}\text { Pelaksana kegiatan dan Kelompok } \\
\text { pengrajin eceng gondok. }\end{array}$ \\
\hline 3. & Diskusi rencana kebutuhan pelaksanaan kegiatan & $\begin{array}{l}\text { Pelaksana kegiatan dan Kelompok } \\
\text { pengrajin eceng gondok. }\end{array}$ \\
\hline
\end{tabular}


Buchari. et al. Peningkatan Mutu Produk Kelompok Usaha Pengrajin Eceng Gondok...

\begin{tabular}{|c|c|c|}
\hline No & Kegiatan & Pelaksana \\
\hline \multirow[t]{2}{*}{4.} & $\begin{array}{l}\text { Menentukan jadwal pelaksanaan kegiatan pelatihan dan } \\
\text { praktek }\end{array}$ & $\begin{array}{l}\text { Pelaksana kegiatan dan Kelompok } \\
\text { pengrajin eceng gondok. }\end{array}$ \\
\hline & $\begin{array}{l}\text { Diskusi jenis partisipasi mitra untuk mendukung } \\
\text { pelaksanaan kegiatan }\end{array}$ & $\begin{array}{l}\text { Pelaksana kegiatan dan Kelompok } \\
\text { pengrajin eceng gondok. }\end{array}$ \\
\hline B. & Pelaksanaan Kegiatan Pengabdian & \\
\hline \multirow[t]{3}{*}{1.} & $\begin{array}{l}\text { Kunjungan ke lokasi kelompok pengrajin eceng gondok } \\
\text { Kelurahan Semula jadi, Kec Datuk Bandar Timur Kota } \\
\text { Tanjung Balai, Selasa-Rabu, 25-27 Oktober } 2016\end{array}$ & \\
\hline & $\begin{array}{l}\text { 1.a Persiapan kebutuhan pendukung bagi kegiatan } \\
\text { pelatihan dan praktek }\end{array}$ & $\begin{array}{l}\text { Pelaksana kegiatan dan Kelompok } \\
\text { pengrajin eceng gondok. }\end{array}$ \\
\hline & $\begin{array}{l}\text { 1.b Persiapan Bahan-bahan dan alat yang dipakai pada } \\
\text { pelatihan dan praktek }\end{array}$ & $\begin{array}{l}\text { Pelaksana kegiatan dan Kelompok } \\
\text { pengrajin eceng gondok. }\end{array}$ \\
\hline \multirow[t]{3}{*}{2.} & $\begin{array}{l}\text { Implementasi kegiatan program pengabdian hari pertama, } \\
\text { Selasa, } 25 \text { Oktober } 2016\end{array}$ & \\
\hline & $\begin{array}{l}\text { 2.a Pelatihan Memintal eceng gondok secara manual } \\
\text { untuk bahan membuat produk inovasi kursi, meja } \\
\text { dan sandal (Jam } 08.00-12.00 \text { WIB) }\end{array}$ & $\begin{array}{l}\text { Pelaksana kegiatan dan Kelompok } \\
\text { pengrajin eceng gondok. }\end{array}$ \\
\hline & $\begin{array}{l}\text { 2.b Pelatihan desain dan praktek membuat produk } \\
\text { inovasi meja berbahan eceng gondok dan rotan (Jam } \\
\text { 13.00-16.00 WIB) }\end{array}$ & $\begin{array}{l}\text { Pelaksana kegiatan dan Kelompok } \\
\text { pengrajin eceng gondok. }\end{array}$ \\
\hline \multirow[t]{3}{*}{3.} & $\begin{array}{l}\text { Implementasi kegiatan program pengabdian hari kedua, } \\
\text { Rabu, } 26 \text { Oktober } 2016\end{array}$ & \\
\hline & $\begin{array}{l}\text { 3.a Pelatihan lanjutan pembuatan kursi berbahan eceng } \\
\text { gondok dengan sentuhan kreatifitas pada bentuk, } \\
\text { motif dan warna. }(08.00-12.00 \text { WIB) }\end{array}$ & $\begin{array}{l}\text { Pelaksana kegiatan dan Kelompok } \\
\text { pengrajin eceng gondok. }\end{array}$ \\
\hline & $\begin{array}{l}\text { 3.b Pelatihan dan praktek teknik pewarnaan dengan } \\
\text { menggunakan gun spray + compresor dan teknik } \\
\text { celup (jam 13.00-16.00 WIB }\end{array}$ & $\begin{array}{l}\text { Pelaksana kegiatan dan Kelompok } \\
\text { pengrajin eceng gondok. }\end{array}$ \\
\hline \multirow[t]{2}{*}{4.} & $\begin{array}{l}\text { Implementasi kegiatan program pengabdian hari ketiga, } \\
27 \text { Oktober } 2016\end{array}$ & \\
\hline & $\begin{array}{l}\text { 4.a Pelatihan desain dan praktek pembuatan sandal } \\
\text { berbahan eceng gondok dengan sentuhan kreatifitas } \\
\text { pada bentuk, motif dan warna. (08.00-12.00 WIB) }\end{array}$ & $\begin{array}{l}\text { Pelaksana kegiatan dan Kelompok } \\
\text { pengrajin eceng gondok. }\end{array}$ \\
\hline C. & Monitoring dan evaluasi hasil kegiatan pengabdian & \\
\hline 1. & $\begin{array}{l}\text { Monitoring dan evaluasi dilakukan oleh Tim Monev } \\
\text { LPPM USU }\end{array}$ & $\begin{array}{l}\text { Pelaksana kegiatan dan Tim Monev } \\
\text { LPPM USU }\end{array}$ \\
\hline 2. & $\begin{array}{l}\text { Memasukkan laporan kegiatan dan keuangan ke LPPM } \\
\text { USU }\end{array}$ & Pelaksana kegiatan \\
\hline
\end{tabular}

\section{Memintal Eceng Gondok Secara Manual}

Tahap awal sebelum membuat produk inovasi, para pengrajin beserta tim dilatih cara memintal eceng gondok secara manual. Teknik memintal yang digunakan dengan cara mengepang eceng gondok sehingga membentuk kepangan yang bagus dan rapi. para pengrajin dilatih teknik mengepang eceng gondok yang telah dikeringkan. Eceng gondok yang sudah dikepang akan digunakan sebagai bahan untuk pembuatan kursi dan meja. Para pengrajin langsung mempraktekkan cara mengepang eceng gondok yang telah dikeringkan. Kegiatan ini dapat dilihat pada gambar berikut. 
Buchari. et al. Peningkatan Mutu Produk Kelompok Usaha Pengrajin Eceng Gondok...

Gambar.

Para Pengrajin Mengepang Eceng Gondok yang Telah Dikeringkan
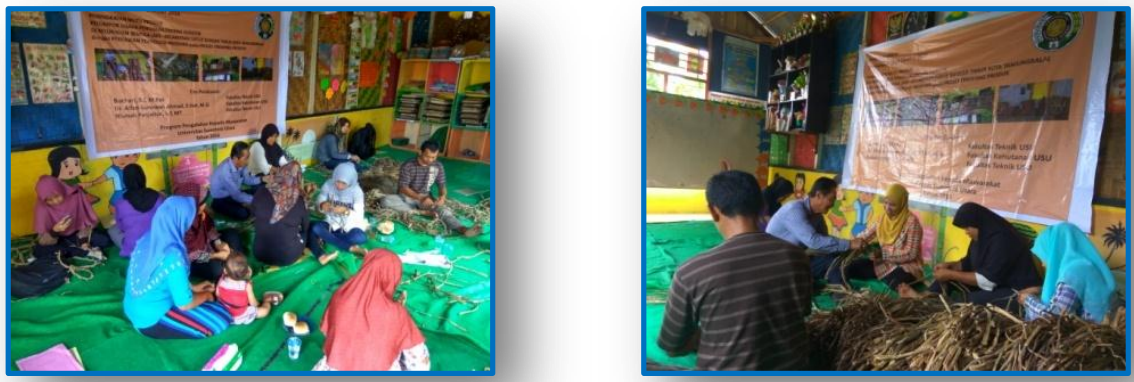

\section{Pelatihan Pembuatan Produk Inovasi Kursi dan Meja Berbahan Eceng Gondok}

Setelah semua eceng gondok selesai dipintal secara manual, kegiatan selanjutnya adalah pengembangan produk inovasi kelompok usaha pengrajin eceng gondok melalui pelatihan pembuatan produk inovasi kursi dan meja berbahan eceng gondok. Pembuatan kursi berbahan eceng gondok dilakukan pada hari selasa, 25 oktober 2016, pukul 13.00-16.00 WIB. Sedangkan pelatihan pembuatan meja berbahan eceng gondok dilakukan pada hari rabu, 26 Oktober 2016.
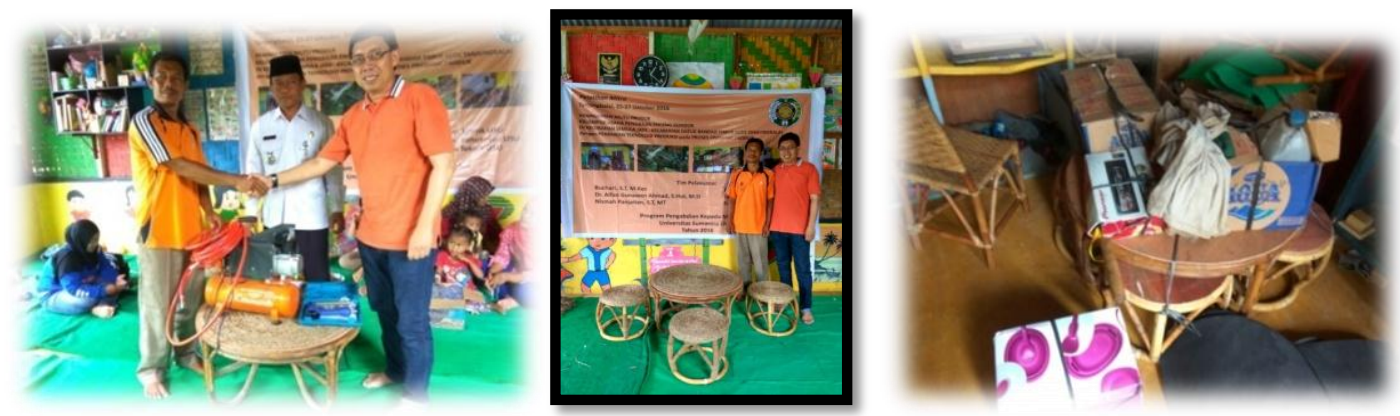

\section{Pelatihan Teknik Pewarnaan}

Setelah selesai membuat kursi dan meja, para pengrajin eceng gondok dilatih beberapa teknik-teknik dalam pewarnaan produk. Pewarnaan produk merupakan kegiatan finishing produk untuk mengoptimalkan kualitas, tampilan dan daya jual produk. Dalam kegiatan pelatihan tersebut, instruktur melatih dua teknik pewarnaan, yaitu:

1. Teknik pewarnaan dengan menggunakan gun spray dengan bantuan kompresor.

2. Teknik pewarnaan dengan teknik celup.

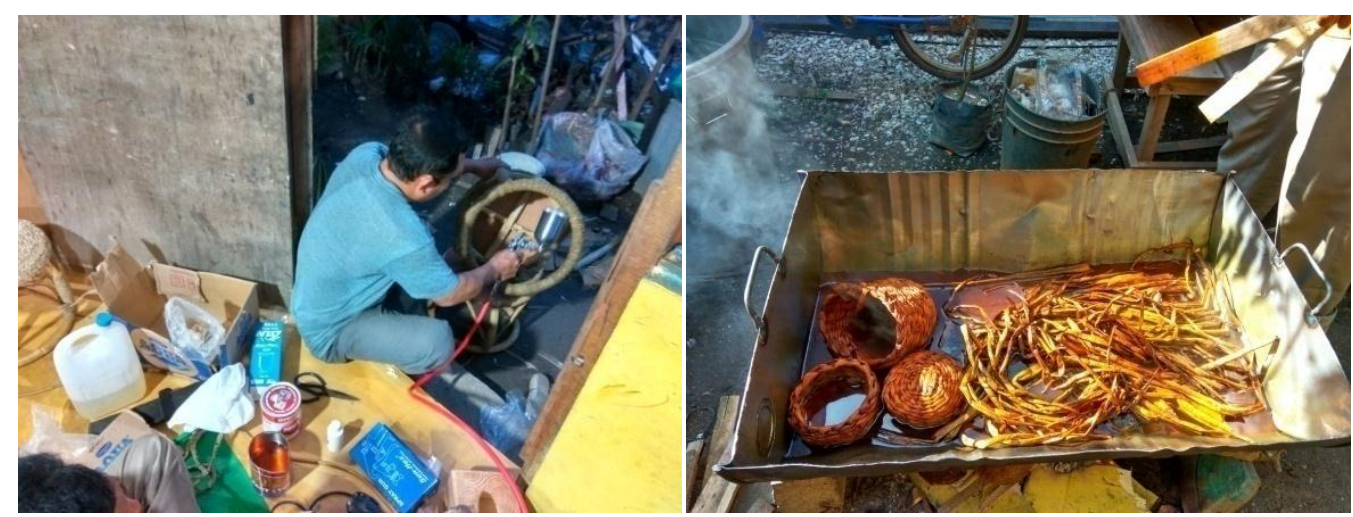


Buchari. et al. Peningkatan Mutu Produk Kelompok Usaha Pengrajin Eceng Gondok...

\section{Pelatihan Pembuatan Produk Inovasi Sandal Berbahan Eceng Gondok}

Di hari ketiga pelatihan, para pengrajin eceng gondok mengikuti pelatihan inovasi produk pembuatan produk sandal dengan bahan eceng gondok. Adapun Tahapan pembuatan sandal, diantaranya : Pertama, pembuatan cetakan sandal pada karton sesuai ukuran kaki para pengrajin Kedua, cetakan kaki berbentuk karton ditempelkan pada media yang berbentuk anyaman. Ketiga, membuat lubang pada tiga sisi untuk memasukkan tali sandal yang terbuat dari eceng gondok. Keempat, Sisi bagian bawah sandal setengah jadi tersebut diberi lem kambing, kemudian anginanginkan beberapa menit. Kelima, tempelkan pita pada sisi keliling sandal agar menutupi bentuk yang ttidak rata. Pita digunakan untuk mempercantik sisi keliling sandal agar terlihat rapi. Pita ditempel dengan menggunakan lem, sisi lebar pita yang berlebih ditempelan secara teratur ke sisi samping atas sandal. Proses kegiatan ini dapat dilihat pada gambar berikut.
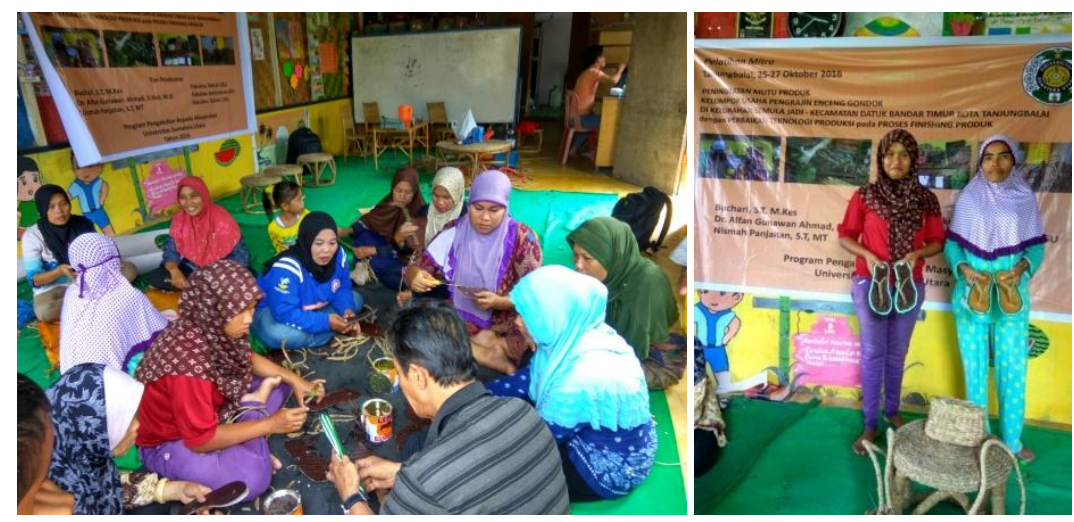

\section{Kesimpulan}

1. Adanya transfer teknologi inovasi dari perguruan tinggi terhadap kelompok pengrajin eceng gondok Semula Jadi melalui inovasi produk dan teknik pewarnaan dengan gun spray dan teknik celup.

2. Pelatihan yang diberikan bagi kelompok pengrajin eceng gondok adalah pelatihan inovasi produk kursi dan meja meja, dan Pelatihan teknik pewarnaan, kemudian pelatihan inovasi produk pembuatan sandal berbahan eceng gondok.

3. Teknik pewarnaan yang diberikan kepada kelompok pengrajin eceng gondok Desa Semula Jadi adalah teknik pewarnaan dengan menggunakan gun spray yang dibantu compresor dan teknik pewarnaan dengan teknik celup.

\section{Saran}

1. Perlu dilakukan pendampingan dalam meningkatkan mutu produk pengrajin eceng gondok, diantaranya dengan pendampingan yang akan dilakukan oleh Dinas Perindustrian dan Perdagangan Kota Tanjung Balai

2. Para pengrajin membutuhkan alat potong untuk menyempurnakan produk sandal yang dihasilkan supaya rapi potongannya.

\section{Daftar Pustaka}

Badan Pusat Statistik. 2010. Indonesia Dalam Angka 2010. Jakarta : Badan Pusat Statistik

Ginting, Rosnan. 2007. Perancangan Produk. Yogyakarta : Graha Ilmu

Sinulingga, Sukaria. 2008. Pengantar Teknik

Industri. Edisi Pertama. Yogyakarta : Graha

Ilmu 